〔農村医学 27 巻 1 号 75 78頁 昭. 53.4〕

\title{
A CASE OF DIPHYLLOBOTHRIASIS FROM EHIME PREFECTURE
}

\author{
Kazumitsu HIRAI, Hiroshi NISHIDA \& Kuninori SHIWAKU*
}

\section{Introduction}

Diphyllobothriasis is an invasion of intestines by tapeworms belonging to the genus Diphyllobothrium, of which the best or only known species in Japan is the "fish tapeworm" Diphyllobothrium latum (L. 1758). In Japan, humans become infected by eating raw or insufficiently cooked salmoniids, especially the "Sakuramasu" Oncorhyncus masou (Brevoort), so diphyllobothriasis is mostly reported from river areas along the coast of the Japan Sea, from northern district of Kyoto to Hokkaido, ${ }^{1)}$ where the spawning migration of salmoniids is found. Though some cases are described sporadically from various parts of Japan, very little is known in Ehime Prefecture. Recently, spread of the disease is favored by developing transportation, increasing tourism, and a return to primitive eating habits etc. ${ }^{2)} 3$ ) Moreover, Kamo et al.4) 5)(1973) suggested the occurrence of some cases infected with certain marine species of the other than Diphyllobothrium latum. Therefore, careful studies on ecological aspects of each case and on the morphology of each worm specimen will be necessary to clarify the mode of infection and taxonomic situation of the genus in Japan.

\section{Case Report}

The patient, Y. H., 35-year-old male, is a painter living in Matsuyama City in Ehime Prefecture.

Chief complaint: Evacuation of a ribbon-like worm with stool.

Family history : Non contributory.

Present history: He has had a poor digestion for a long time, suffering occasionally from diarrhea and abdominal pains. He found out in his stool a ribbonlike worm (about $370 \mathrm{~cm}$ long). Then he visited the outpatient clinic of a local hospital, taking with him the worm specimen, which was forwarded to our laboratory for identification. He presented wide varieties of symptoms such as malaise, abdominal pains, diarrhea, vertigo and irritation.

Laboratory finding : Numerous ova of typical diphyllobothriid cestodes were detected in his feces, whereas neither anemia nor eosinophilia on the blood examination, nor disturbance in the liver function was detectable.

On July 3rd 1976, he expelled a tapeworm (about $900 \mathrm{~cm}$ long with scolex)as the result of administration of bithionol $(3.0 \mathrm{~g})$ with purgative (magnessium sulfate). He had never eaten any raw fish, except for only one occasion of eating salmon in "Sashimi" slice of the raw fish on one day in April, 1976.

\section{Morphological Examination of the Worm}

The scolex was more or less spoon-shaped (lateral view), and its size was $2.5 \mathrm{~mm}$ (length) $\times 1.2 \mathrm{~mm}$ (maximum width) $\times 0.8 \mathrm{~mm}$ (thickness). Bothria were deep, extending the full length of the scolex. The strobila was relatively thin, translucent, attenuated anterioly, widening posteriad to maximum of $14 \mathrm{~mm}$ with serrated margines. Anterior segments were wider than long, with length/width ratio increasing posteriad. The length/width ratio of gravid segments was about 0.2 .

The common genital atrium and the uterus opened ventrally on the midline, in the anterior one-fourth of the segment, where two pores were situated on the surface of a distension extending about from the anterior margine of the segment posteriad to a level just posterior to the uterine pore. Rounded papillae covered distended poral area and were present within the genital atrium.

* Department of Parasitology, Ehime University School of Medicine, Shigenobu-cho, Ehime Prefecture, Japan. 
The cirrus sac was thick-walled, piriform in shape, with long axis directed anterodorsad. The external seminal vesicle was situated dorsally, immediately posterior to the cirrus sac. The testes were arranged in a single layer and were characteristically restricted in distribution to disjunct, lateral fields, usually extending mediad among the loops of the gravid uterus and sometimes overlapping lateral margines of the overy. Vitelline follicles were also restricted to disjunct, lateral fields, both ventrally and dorsally. The vagina turned abruptly ventrad making an angle of about $60^{\circ}$ at the level of the ventral surface of the external seminal vesicle, there just posterior to the wall of the cirrus sac.

The ovary consists of bilateral, wing-like lobes connected by a narrow isthumus. The lobes, made up of a loose reticulum of tubules, extended laterad into the respective lateral fields of the segment. The gravid uterus usually extended anteriad beyond the level of the posterior margine of the cirrus sac, there after running posteriad to the uterine pore, forming an acute angle with the ventral surface of the segment. Eggs were ovoid, operculated, with the average size of $84.6 \times 59.9 \mu$. Shallow pits were observed on the surface of the egg-shell by the scanning electron microscopy.

\section{Discussion}

The difficulty in identifing cestodes of the genus Diphyllobothrium has been attributed to inadequate knowledge of the limits of intraspecific morphological variation and of factors responsible for such extrinsic variation. "However, we believe that morphological characters of reliable diagnostic value can be defind for species of this genus through comparative study of large series of each from in question", as stated by Rausch et Hilliard, $(1970)^{6}$. Sevral species belonging to the genus Diphyllobothrium are described in man from different parts of the world, whereas Diphyllobothrium latum is a only species kown to occur in Japan. Recently some marine species of the genus were suggested as the cause of certain human cases in western part of Japan by Kamo et al. (1973) ${ }^{4}$, who proposed the necessity of reconsideration on taxonomic status of the genus in Japan. It is, therefore, worthwhile to describe in detail on any cases of diphyllobothriasis, especially from western Japan, from epidemiological and taxonomical point of view.

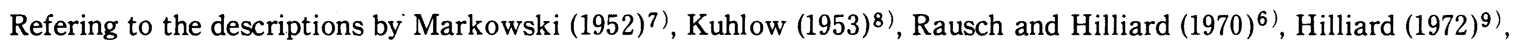
Kamo et al. (1973) ${ }^{4}$, and Andersen $(1975)^{10)}$, we considered the defferential characters of Diphyllobothrium latum to be : (1) thin weakly muscled strobila, with clavate scolex, (2) genital pore and uterine pore widely separated, (3) vagina turning abruptly ventrad just ventral to seminal vesicle, usually forming an angle of near $60^{\circ}$, (4) distal end of uterus extending posteromediad to uterine pore, forming an acute angle with ventral surface of segment, (5) there is constriction between segments and often an area without testes and vitellaria, (6) ovary varies somewhat in shape, but with no anterior horns seen, (7) the smooth surface of the egg-shell with shallow and widely spaced pits in the scanning electron micrograph.

Our specimen was identified as Diphyllobothrium latum, for it presented all these morphological characters.

\section{Summary}

Some fragments of gravid proglottids of diphyllobothriid cestodes were evacuated spontaneously, and complete strobila with scolex was expelled after the treatment with bithionol from a 35-year-old man in Ehime Prefecture, Where diphyllobothriasis has scarcely been recorded. The cestodes was identified as Diphyllobothrium latum by the following morphological characters: thin, weakly muscled strobila, with clavate scolex; distal end of uterus extending posteromediad to uterin pore, forming an acute angle with ventral surface of segment, genital pore and uterine pore widely separated ; vagina turning abruptly ventrad just ventral to seminal vesicle, forming an angle of near $60^{\circ}$; there is a constriction between segments and often an area without testes and vitellaria; ovary with no anterior horns seen; the smooth surface of the egg-shell with shallow and widely spaced pits (scanning electron micrograph)

\section{ACKNOWLEDGEMENTS}

We are deeply grateful to Dr. Takeshi Miyamoto for his help in clinical examinations, and thanks are due to Mr. Daizaburo Shimizu for his assistance in the scanning electron microscopic survey. The help of Mr. Masahiro Sakai is ackowledged. 

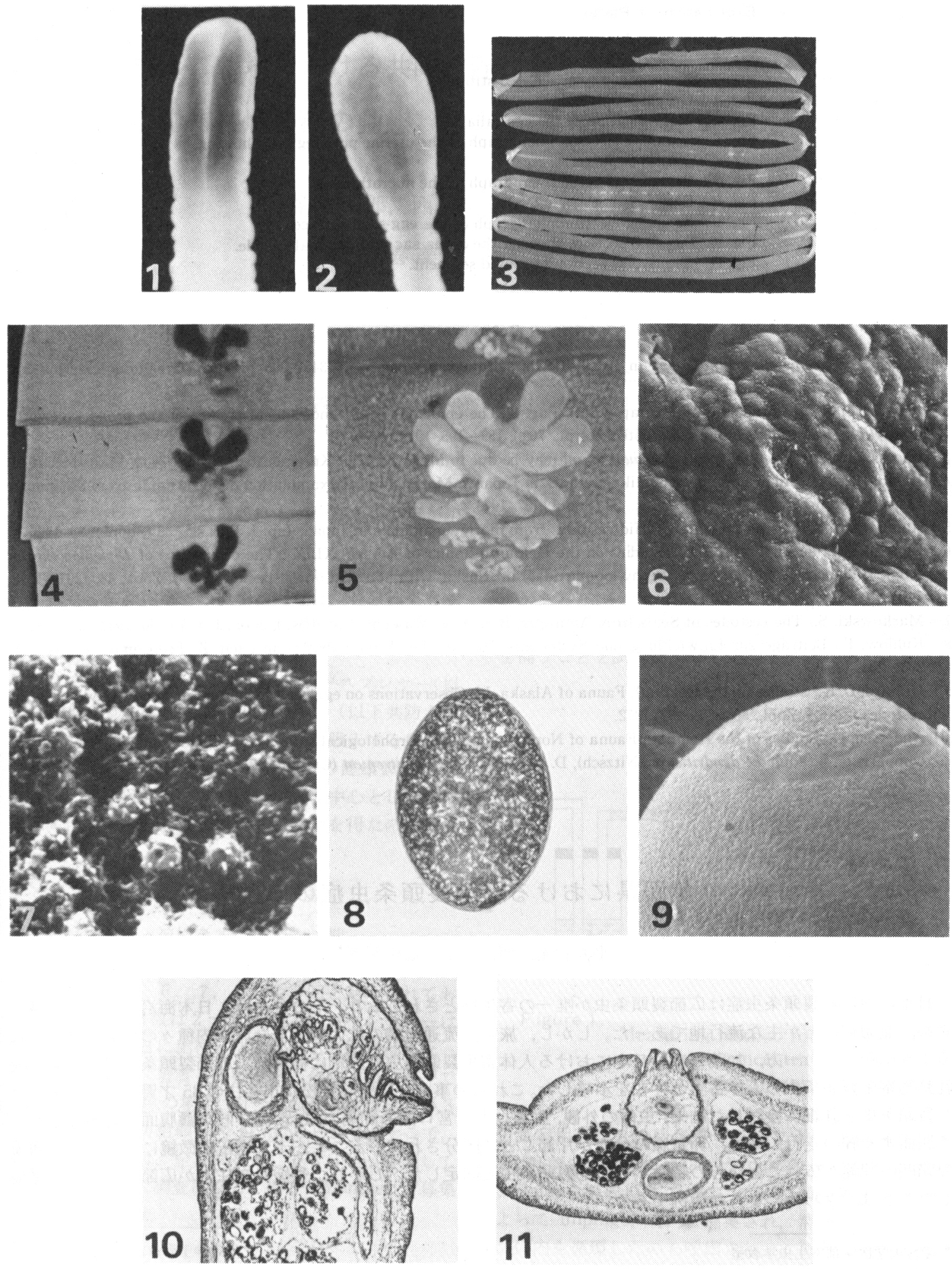


\title{
Explanation of Plates
}

Fig. 1. Scolex, dorso-ventral veiw.

Fig. 2. Scolex, lateral veiw.

Fig. 3. Spontaneously evacuated strobila.

Fig. 4. Gravid proglottid.

Fig. 5. Magnification of the genitalia.

Fig. 6. Scanning electron micrograph of the uterine pore region, showing genital papillae.

Fig. 7. Scanning electron micragraph of the microthriches.

Fig. 8. Egg.

Fig. 9. Scanning electronmicrograph of the egg-shell surface.

Fig. 10. Saggital section, showing the cirrus sac and seminal vesicle.

Fig. 11. Transverse section of gravid segment.

\section{References}

1 ) Eguchi, S.: "Diphyllobothrium latum" in Studies on Parasitologỳ in Japan, vol.4 345-356, Meguro Parasitological Museum, Tokyo, 1964.

2 ) Kihara, T. et al :: Studies on large tapeworm. Part 2. The epidemiological and clinical studies of the broad tapeworm (Diphyllobothrium latum). Jap. J. Gastroenterol., 70(3), 189-195, 1972.

3 ) Cho, H. et al.: A case of Diphyllobothrium latum may be due to Masu-zushi. J. Kurume Med. Assoc., 38(12), $1453-1456,1975$.

4 ) Kamo, H. et al.: Studies on the latum-like cestodes in Japan 2. Morphological examination of the strobila from the human cases in Sanin District. Jap. J. Parasit., 22 (Suppl.), 87, 1973.

5 ) Kamo, et al :: Notes on diphyllobothriid cestodes from marine mammals in Japan. Jap. J. Parasit., 25 (Suppl.), $33,1976$.

6 ) Rausch, R. L. and Hilliard, D. K.: Studies on the Helminth Fauna of Alaska. XLIX : The occurrence of Diphyllobothrium latum (Linnaeus, 1758) (Cestoda : Diphyllobothriidae) in Alaska, with notes on other species. Can. J. Zool., 48, 1201-1219, 1970.

7 ) Markowski, S.: The cestodes of Seals from Antarctic. Bull. Brit. Museum (Nat. Hist.), zool., 1, 125-150, 1952.

8 ) Kuhlow, F.: Beiträge zur Entwicklung und Systematik Helminscher DiphyllobothriumArten. Z. Tropenmed. Parasit., 4, 203-234, 1954.

9 ) Hilliard, D. K.: Studies on the Helminth Fauna of Alaska. LI. Observations on egg-shell formation in some diphyllobothriid cestodes. Can. J. Zool., 50, 585-592, 1972.

10) Andersen, K.: Studies of the Helminth Fauna of Norway XXXIV; Morphological stability of Diphyllobothrium Cobbold. A comparision of adult D. dendriticum (Nitzsch), D. latum (L.) and D. ditrenum (Creplin) developed in different host. Norw. J. Zool., 23, 45-53, 1975.

〈抄録〉

\section{愛媛県における広節裂頭条虫症の 1 例}

\author{
平井和光, 西田 弘, 塩飽邦憲*
}

日本における裂頭条虫症は広節裂頭条虫が唯一の寄生種とされており, その分布は, 日本海沿岸の河川流域, 京都, 北海道などが主な流行地であった。しかし，旅行，流通機構の㧪大にともない国内種々の地域で発見され るようになった。一方，加茂らは，日本における人体寄生裂頭条虫を詳細に検討し，広節裂頭条虫以外の海産哺 乳動物寄生裂頭条虫の人体寄生の存在を示唆した。これらの事実から愛媛県松山市在住の 35 才男子から排出され た裂頭条虫を詳細に検討した結果, 虫体の外観, 生殖口と子宮口間の間隔の広いこと, 眝精豪腹面で急角度をもっ て屈曲する胵の走行, 辠丸, 卵黄腺の分布が片節ごとに区分されていること, 走査電子顕微鏡による卵款表面像 の陥凹の間隔が広いことなどの特改から広節裂頭条虫と同定した。しかし，愛媛県在住者が広節裂頭条虫に感染 したことは，きわめてまれな症例である。

* 愛媛大学医学部寄生虫学教室

受付：昭和 52 年 12 月 2 日 